
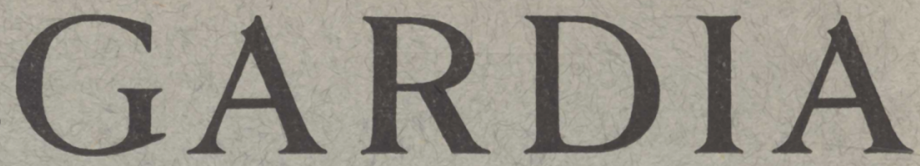

A Journal of Agricultural Science Published by the California Agricultural Experiment Station

\title{
APHID TRANSMISSION OF MILD MOSAIC VIRUS OF ANNUAL STOCK
}

HENRY H. P. SEVERIN and C. M. TOMPKINS

\section{ADDITIONAL VIRUS DISEASES OF SPINACH IN CALIFORNIA}

\author{
HENRY H. P. SEVERIN
}

UNIVERSITY OF CALIFORNIA - BERKELEY, CALIFORNIA 


\section{CONTENTS}

Aphid Transmission of Mild Mosaic Virus of Annual

Stock, by Henry H. P. Severin and C. M. Tompkins. . . . . . 539

Summary $\ldots \ldots \ldots \ldots \ldots \ldots \ldots \ldots \ldots \ldots \ldots \ldots . \ldots 539$

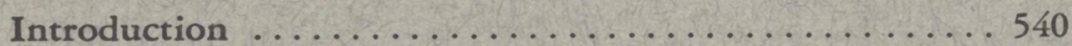

Materials and methods................... 540

Distribution $\ldots \ldots \ldots \ldots \ldots \ldots \ldots \ldots \ldots \ldots \ldots \ldots 1$

Symptomatology $\ldots \ldots \ldots \ldots \ldots \ldots \ldots \ldots \ldots \ldots \ldots . \ldots 41$

Apbid transmission of virus . . . . . . . . . . . 541

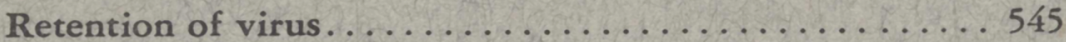

Loss and recovery of infectivity by turnip aphid....... 546

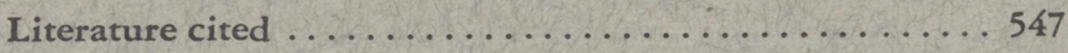

Additional Virus Diseases of Spinach in California, by

Henry H. P. Severin . . . . . . . . . . . . . 553

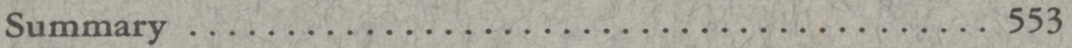

Introduction $\ldots \ldots \ldots \ldots \ldots \ldots \ldots \ldots \ldots \ldots \ldots \ldots \ldots \ldots \ldots \ldots \ldots$

Western cucumber mosaic . . . . . . . . . . . . 554

Celery calico ........................ 555

Sugar-beet mosaic . . . . . . . . . . . . . . . 555

Aphid vectors $\ldots \ldots \ldots \ldots \ldots \ldots \ldots \ldots \ldots \ldots \ldots 57$

Literature cited $\ldots \ldots \ldots \ldots \ldots \ldots \ldots \ldots \ldots \ldots \ldots \ldots \ldots$ 


\title{
ADDITIONAL VIRUS DISEASES OF SPINACH IN CALIFORNIA ${ }^{1}$
}

\author{
HENRY H. P. SEVERIN ${ }^{2}$
}

\section{SUMMARY}

Spinach was demonstrated to be naturally infected in California with sugarbeet mosaic and two cucumber mosaics-western cucumber mosaic and celery calico. Nine varieties of spinach were experimentally infected with the two cucumber mosaic viruses, five with sugar-beet mosaic. The three viruses were recovered from naturally infected spinach and transferred by mechanical inoculation to White Spine cucumber (Cucumis sativus), Turkish tobacco (Nicotiana tabacum), N. glutinosa, or sugar beet (Beta vulgaris).

The symptoms of these three diseases on spinach are similar. Filamentous leaves occur only in western cucumber mosaic. But cleared venation, chlorotic spotting, blisterlike elevations, and necrosis occur in all three. The viruses can be distinguished by transferring them to sugar beets; on that host the symptoms are sufficiently distinctive to permit identification.

New Zealand spinach (Tetragonia expansa) was experimentally infected with western cucumber mosaic, and the virus was recovered and transferred to White Spine cucumber and sugar beet.

The green peach aphid, Myzus persicae (Sulzer), is the most important vector of the western-cucumber-mosaic, celery-calico, and sugar-beet-mosaic viruses to spinach under natural conditions. The bean or dock aphid, Aphis rumicis Linnaeus, rarely transmits these viruses.

\section{INTRODUCTION}

Five virus diseases have been reported to occur on spinach (Spinacia oleracea, family Chenopodiaceae) under natural conditions in California; namely, aster yellows (Severin, 1934; Severin and Frazier, 1945), ${ }^{3}$ sugarbeet curly top (Severin and Henderson, 1928; Scott, 1935), sugar-beet mosaic (Severin and Drake, 1948), spinach yellow dwarf (Severin and Little, 1947), and spotted wilt (Gardner, Tompkins, and Thomas, 1937)

This paper deals with two additional naturally occurring virus diseases of spinach - western cucumber mosaic and celery calico — and with sugar-beet mosaic on this host. Studies were made of the succession of symptoms on naturally and experimentally infected spinach caused by the three viruses. The symptoms of western cucumber mosaic were also studied on New Zealand spinach, Tetragonia expansa, which belongs to the family Aizoaceae. No insecttransmission tests are reported here. But previous reports on aphid transmission and on the aphid species naturally occurring on spinach are reviewed to determine which species are important vectors of the viruses.

\footnotetext{
${ }^{1}$ Received for publication May 11, 1948.

2 Entomologist in the Experiment Station.

${ }^{3}$ See "Literature Cited" for citations, referred to in the text by author and date.
} 


\section{WESTER.N CUCUMBER MOSAIC}

Western cucumber mosaic occurs on several hosts in interior regions of California, but has not been found to occur naturally outside this region.

Outbreaks. During the spring of 1947 , spinach in one 30 -acre field near Patterson, in the northern San Joaquin Valley, was badly affected with yellowing of the foliage and rotting of the heart leaves. At first the injury was attributed to killing of the heart leaves by frosts. There was no evidence, however, of similar symptoms on spinach in other fields in the same district.

Later Bacon and Walz (1947) demonstrated that the rotting of the heart leaves resulted from the injuries of the seed-corn maggot, Hylemya cilicrura (Rondani), which also destroyed the young crown leaves of many plants.

Yellowing of the foliage, however, was present on many plants that showed no evidence of injury by the seed-corn maggot. On such plants the leaves showed large, blisterlike elevations (plate $1, A, B$ ); some were malformed, thick, and leathery (plate $1, B, C$ ). Since these symptoms suggested a virus disease, attempts were made to recover a virus. The western-cucumber-mosaic virus was recovered from spinach plants with yellow foliage, whether they showed injury from seed-corn maggot or not; it was transferred by the carborundum method (Rawlins and Tompkins, 1936) to sugar beets, which developed the typical symptoms (Severin and Freitag, 1948).

During the spring of 1948 , a serious outbreak of western cucumber mosaic occurred on spinach in many fields near Westley and Patterson. The spinach turned yellow in one 40-acre field planted in September and was disked up in December. The 40 acres were replanted and again the spinach turned yellow and again was disked up. The virus was recovered from the second planting and transferred to sugar beets and squash. Spinach was demonstrated to be naturally infected with western cucumber mosaic in five other fields.

Symptoms. A noticeable symptom on naturally infected spinach, when the fields were viewed from a distance, was the yellow color of the entire plants, or yellow outer and green inner leaves; numerous dried or dead plants could be seen. A closer examination of some infected plants showed cleared veinlets on the youngest leaves (plate 2,A); and on intermediate leaves, circular chlorotic areas (plate $2, C$ ), yellow blotches (plate $2, B$ ), and necrotic areas in the yellow blotches (plate $2, D$ ). Blisterlike elevations and malformations occurred on the heart leaves (plate $3, A, B$ ). In the late stage of the disease, the youngest leaves are misshapen (plate $3, D$, upper row) and frequently surround filamentous leaves (plate $3, D$, lower row). When infected plants develop seedstalks, the filamentous leaves are very conspicuous (plate $3, C$ ). In 1947 the blisterlike elevations were the prevailing symptom; in 1948 the filamentous leaves were prevalent and the blisterlike elevations rare.

The first symptom to appear on the youngest leaves of experimentally infected Bloomsdale (or Savoy-leafed) spinach is a clearing of the veins and veinlets (plate $4, A$ ), accompanied with small, circular, chlorotic spots (plate $4, A, B)$. The younger leaves become malformed with blisterlike elevations (plate $4, C, D$ ). Sometimes the younger leaves are folded along the midrib. In the late stage of the disease the newly developing leaves of some infected plants are linear, with blades reduced to but little more than the midrib. 
Susceptible Varieties. The following nine varieties of spinach were experimentally infected with western cucumber mosaic : Bloomsdale or Savoy-leafed, Long Standing Bloomsdale, Broad Flanders, Giant Thick-leafed Nobel, Juliana, King of Denmark, Prickly Seeded, Virginia Savoy, and Viroflay.

The virus was recovered from each variety and transferred by mechanical inoculation to White Spine cucumber and to sugar beets.

New Zealand Spinach. The symptoms of western cucumber mosaic which appear on the leaves of New Zealand spinach, Tetragonia expansa, are wide yellow or pale-orange rings surrounding green tissue (plate 5, $A$ ). Later the green areas become chlorotic (plate $5, B$ ) and often fuse (plate $5, C$ ). The leaves frequently become malformed (plate $5, D$ ). The yellow or orange rings may become necrotic. Necrosis of the margin of the leaf occurs. Later the entire leaf becomes dry.

The virus was recovered and transferred by mechanical inoculation to White Spine cucumber.

\section{CELERY CALICO}

Celery calico is a cucumber-mosaic virus which is common in the coastal fog belt and also occurs in the hot interior regions of California.

Natural Infection. The virus of celery calico was recovered from naturally infected spinach plants collected in vegetable fields near San Pablo. The virus extract was mechanically inoculated into healthy Long Standing Bloomsdale spinach, White Spine cucumber (Cucumis sativus), Turkish tobacco (Nicotiana tabacum), and N. glutinosa; typical symptoms of celery calico developed.

Symptoms. The older leaves of naturally infected spinach are lemon yellow (fig. 1, $A$ ). The younger leaves are bunched, narrowed, and deep green, with blisterlike elevations.

The first symptom to appear on the youngest leaves of inoculated varieties of spinach is a clearing of the veins and veinlets (plate $6, A$ ) surrounding green areas (plate $6, B$ ). The next symptom on the youngest leaves is the appearance of blisterlike elevations (plate $6, C$ ); and the youngest developing leaves are narrowed and cupped downward. Later, necrosis of the younger leaves occurs. The oldest leaves become orange or lemon yellow (plate $6, D$ ).

These symptoms are so similar to those of western cucumber mosaic (page 554 ) and sugar-beet mosaic (page 557) on spinach that a field infection of a spinach mosaic disease cannot be certainly identified by the symptoms on that host. It can be identified by transferring the virus to sugar beets; for on that host the symptoms are distinguishable (Severin, 1948).

Susceptible Varieties. The nine varieties of spinach infected with western cucumber mosaic were also experimentally infected with celery calico. The virus was recovered and transferred by mechanical inoculation to White Spine cucumbers, Turkish tobacco, and sugar beets.

\section{SUGAR-BEET MOSAIC}

Natural Infection. Spinach was demonstrated to be naturally infected with sugar-beet mosaic in vegetable gardens near San Pablo. The virus extract from diseased spinach collected in the field was inoculated in healthy spinach and sugar-beet plants, and typical symptoms of the disease developed. 

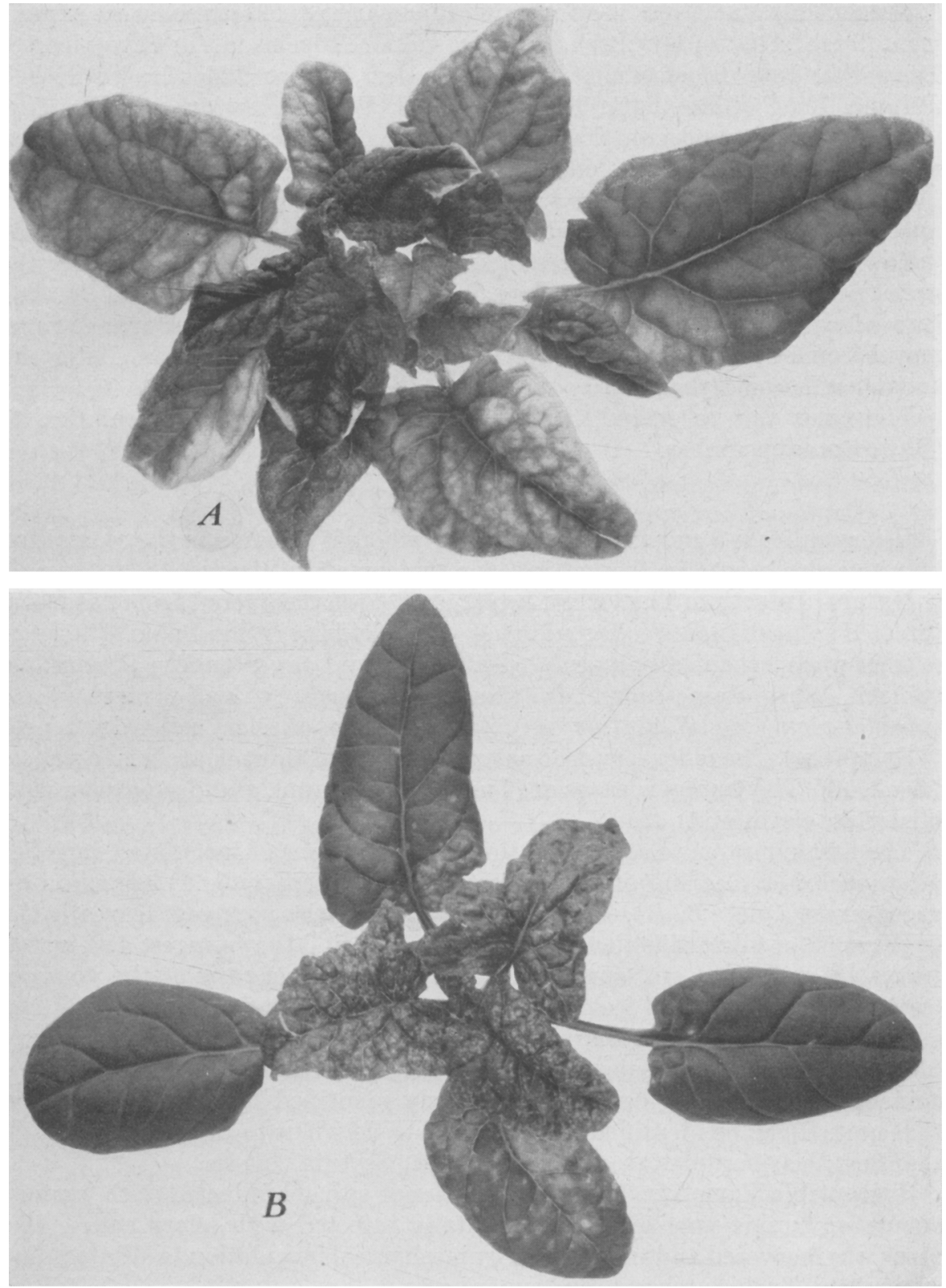

Fig. 1. A, Symptoms of celery calico on a naturally infected plant of Long Standing Bloomsdale spinach, showing older leaves lemon yellow, and younger leaves bunched, narrowed, and deep green, with blisterlike elevations. $B$, Symptoms of sugar-beet mosaic on a plant of Long Standing Bloomsdale spinach, showing small chlorotic areas and cleared veinlets. 
Symptoms. The symptoms on experimentally infected Giant Thick-leafed Nobel, Long Standing Bloomsdale, Prickly Seeded, Virginia Savoy, and Viroflay spinach are similar in most respects. The first symptom to appear is small, chlorotic areas on or between the veinlets and usually near the base of the youngest leaves (plate $7, A$ ). These occur simultaneously with or are followed immediately by a broken type of cleared veinlets (fig. $1, B$ ); in the greenhouse these cleared veinlets appear 10 days after inoculation. Numerous chlorotic rings develop, each with a necrotic center (plate $7, B$ ). The young leaves assume a horizontal position (fig. $1, B$ ). Later the chlorotic rings coalesce to form irregular chlorotic areas intermingled with conspicuous, dark-green, blisterlike elevations (plate $7, C$ ), sometimes followed by chlorotic reinbanding (plate $7, D$ ).

Contrary to Hoggan's (1933) observations, malformation on the youngest leaves is common on infected spinach here. Some dwarfed misshapen leaves show chlorotic areas and others blisterlike elevations (plate $8, A, B$ ); others are twisted along the midribs (plate $8, C$ ) or folded along the midribs (plate $8, D)$. Some of the youngest leaves are cupped outward, others are asymmetrical.

As the disease progresses, the older leaves show chlorotic rings which usually coalesce to form large, irregular, chlorotic areas interspersed with dark-green blotches (plate $8, E$ ). Sometimes the chlorotic areas are smaller and more numerous, and the dark-green areas appear blisterlike, as on the younger leaves.

In the advanced stage of the disease, the older leaves usually show large, irregular, diffuse, yellowish areas which later become dark yellow or orange. Long Standing Bloomsdale and Virginia Savoy spinach developed numerous chlorotic rings, sometimes lenticular in shape, and measuring $4 \mathrm{~mm}$ in diameter, which later become necrotic. On all varieties the older leaves usually develop necrotic tissue at the tip; the necrosis gradually advances toward the base of the leaves; often it occurs along the margin or within the blade (plate $8, F)$. Necrosis gradually spreads over the older leaves and then toward the heart leaves. The dead tissue is papery, brown in color, and suggestive of sunburn. The plant finally dies.

Since spinach was so severely affected by the sugar-beet-mosaic virus, it may be of greater economic importance than is now realized.

Incubation Period. The incubation period of the disease in five varieties of spinach experimentally infected with sugar-beet mosaic ranged from 7 to 15 days. The number of times that the virus was recovered has been reported in a previous paper (Severin and Drake, 1948).

\section{APHID VECTORS}

Patch (1938) lists the following species of aphids as occurring on spinach under natural conditions.

Cotton or melon aphid, Aphis gossypii Glover

Bean or dock aphid, Aphis rumicis Linnaeus

Hyalopterus atriplicis Linnaeus

Potato aphid, Macrosiphum solanifolii Ashmead

Green peach aphid, Myzus persicae (Sulzer) 
Bacon and Walz (1947), who carried on extensive tests on the aphid populations on spinach in the San Joaquin, Santa Clara, and Salinas valleys during the springs of 1946 and 1947, found that the green peach aphid, Myzus persicae, was the most abundant species on spinach. The bean or dock aphid, Aphis rumicis, was occasionally taken on spinach, and some of the females had given rise to small colonies of aphids. Winged forms of the pea aphid, Macrosiphum pisi (Kaltenbach), were observed on spinach but were not multiplying. Previous tests (Severin, 1942; Severin and Freitag, 1948; Severin and Drake, 1948) have shown that the green peach aphid transmits the western-cucumber-mosaic, sugar-beet, and celery-calico viruses; and that the bean aphid rarely transmits the first two. Hence, and also because of its abundance on spinach, the green peach aphid is the most important vector of these viruses to spinach, under natural conditions. The other species of aphids listed by Patch as occurring on spinach were not tested.

\section{LITERATURE CITED}

Bacon, O. G., and A. J. WALZ.

1947. Summary report on spinach insect project. 23 p. Division of Entomology, University of California (Mimeo.).

Gardner, W. M., C. M. Tompkins, and H. H. Thomas.

1937. Factors affecting the prevalence of the spotted-wilt virus. (Abstract.) Phytopathology $27(2): 129$.

HOGGAN, I. A.

1933. Some viruses affecting spinach and certain aspects of insect transmission. Phy. topathology $23: 446-74$.

PATCH, E. M.

1938. Food-plant catalogue of the aphids of the world including the Phylloxeridae. Maine Agr. Exp. Sta. Bul. 393:1-431.

RAwlins, T. E., and C. M. Tompkins.

1936. Studies on the effect of carborundum as an abrasive in plant virus inoculations. Phytopathology 26(6):578-87.

Scotr, G. W.

1935. Spinach production in California. California Agr. Exp. Sta. Cir. 92:1-26. (Out of print.)

Severin, H. H. P.

1934. Transmission of California aster and celery-yellows virus by three species of leafhoppers. Hilgardia 8(10):337-61.

1942. Celery calico on perennial delphiniums and other host plants. Hilgardia 14(8): 441-64.

1948. Symptoms of additional cucumber-mosaic viruses on sugar beets. Hilgardia $18(14): 531-38$.

Severin, H. H. P., and R. M. Drake.

1948. Sugar beet mosaic. Hilgardia $18(13): 483-506$.

Severin, H. H. P., and N. W. Frazier:

1945. California aster yellows on vegetable and seed crops. Hilgardia 16(12):573-96.

Severin, H. H. P., and J. H. Freitag.

1948. Outbreak of western cucumber mosaic on sugar beet. Hilgardia 18(14):523-30.

Severin, H. H. P., and C. F. Henderson.

1928. Some host plants of curly top. Hilgardia 3(13):339-92.

Steverin, H. H. P., and D. H. LitTle.

1947. Spinach yellow dwarf. Hilgardia 17(17):553-66. 

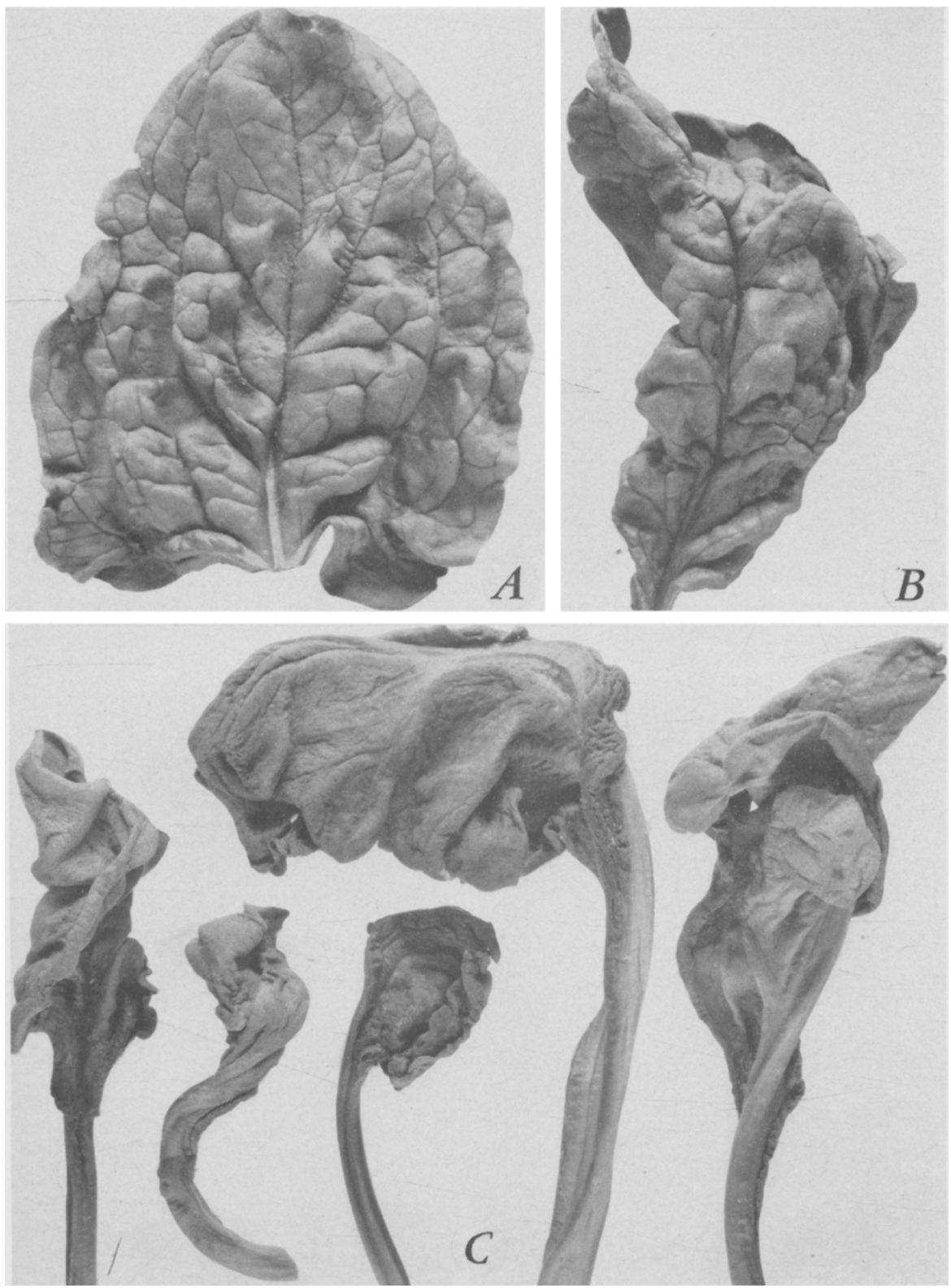

Plate 1. Srmptoms of western cucumber mosaic on leaves of naturally infected spinach, Spinacia oleracea : $A$, blisterlike elevations; $B$, malformed and blistered younger leaf ; $D$, misshapen leaves. 

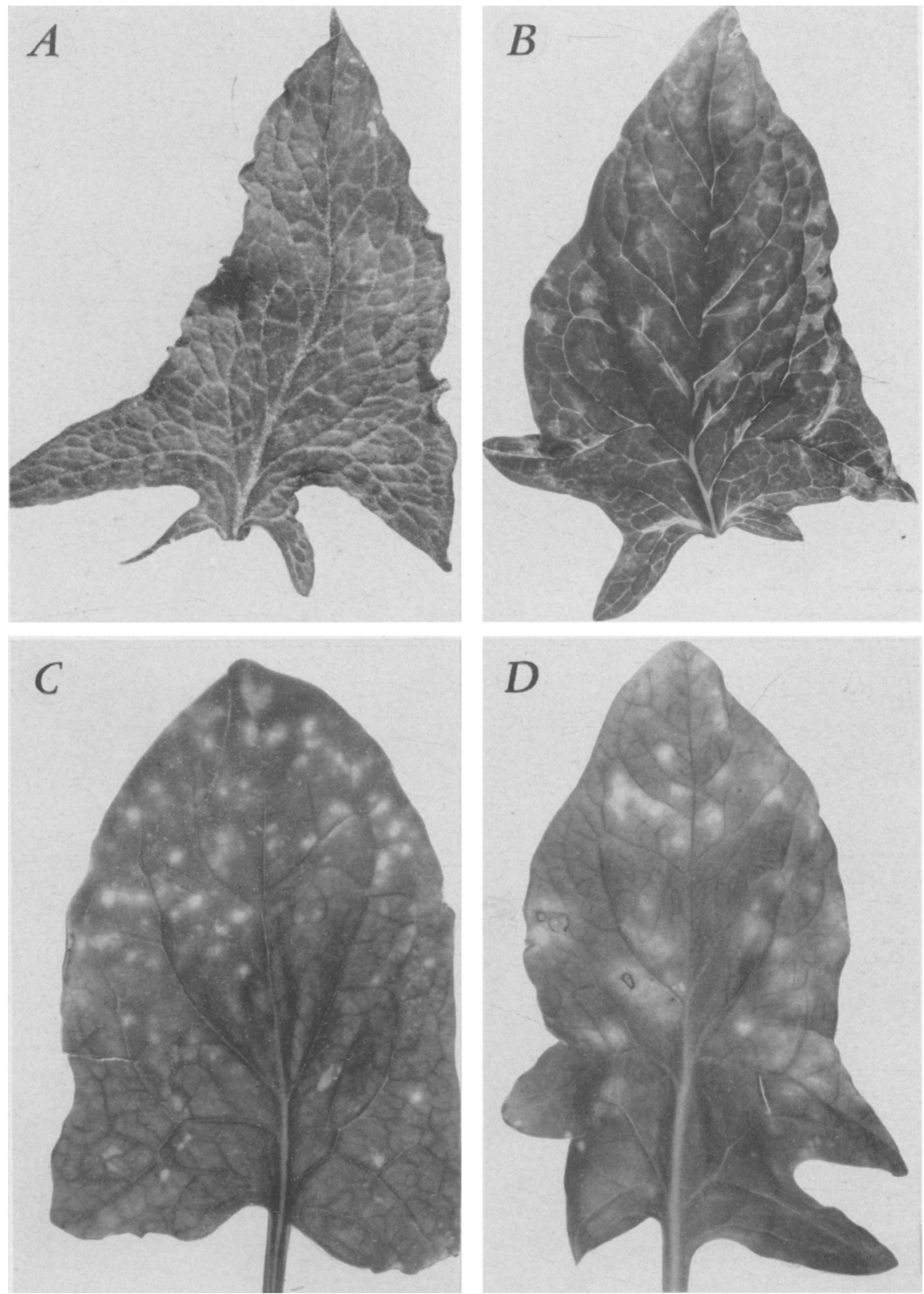

Plate 2. Symptoms of western cucumber mosaic on leaves of naturally infected spinach: $A$, cleared veinlets on youngest leaf; $B$, yellow blotches; $C$, circular chlorotic areas; $D$, necrotic areas in yellow blotches, on intermediate leaf. These symptoms and those shown in plate 1 cannot be distinguished with certainty from corresponding symptoms produced by celery calico and sugar-beet mosaic on spinach. 

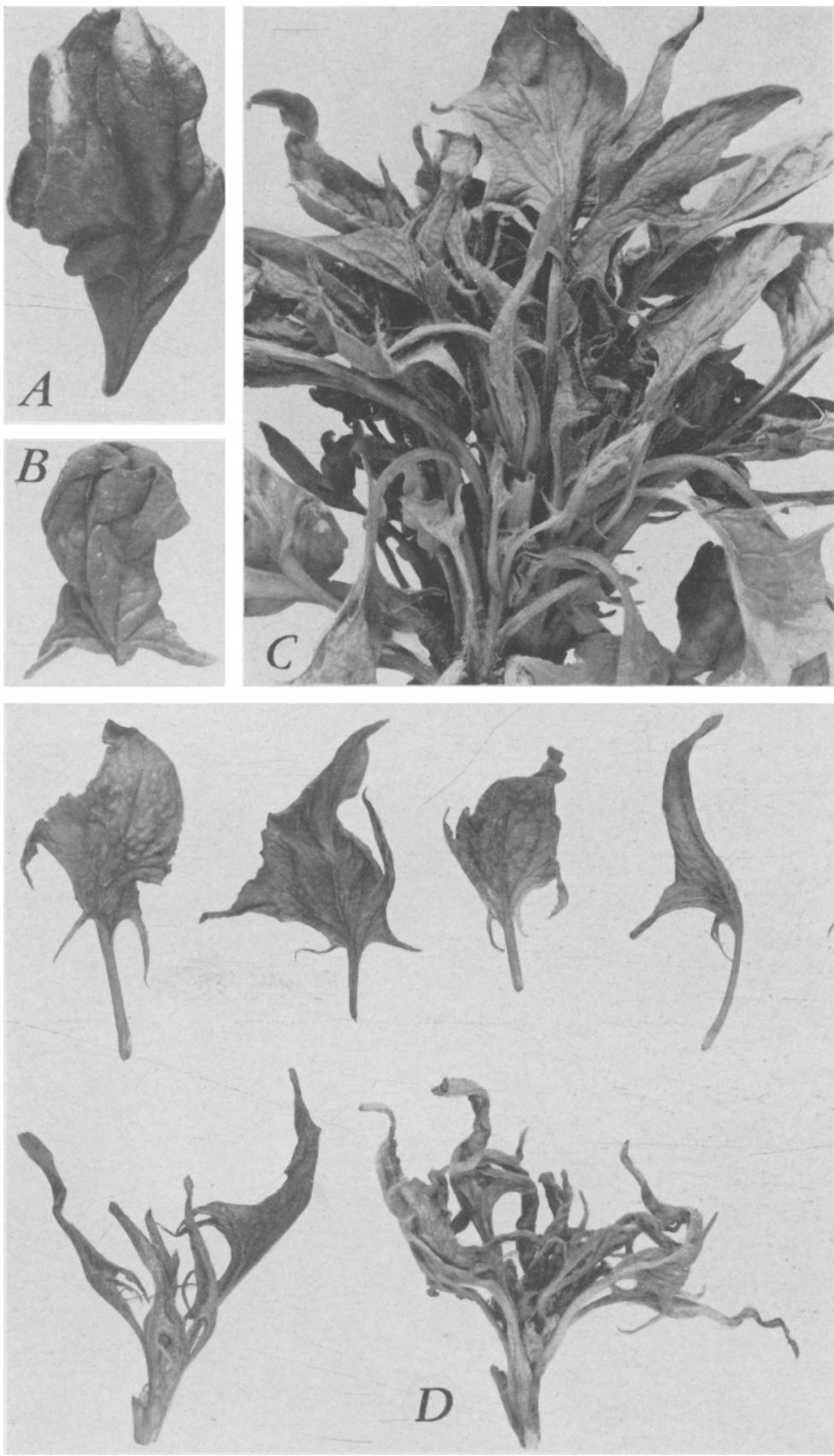

Plate 3. Symptoms of western cucumber mosaic on naturally infected spinach: $A, B$, blisterlike elevations and malformations on heart leaves; $C$, malformed and filamentous leaves growing from seedstalk; $D$, upper row; misshapen leares; $D$, lower row, malformed leaves surrounding filamentous leaves. 

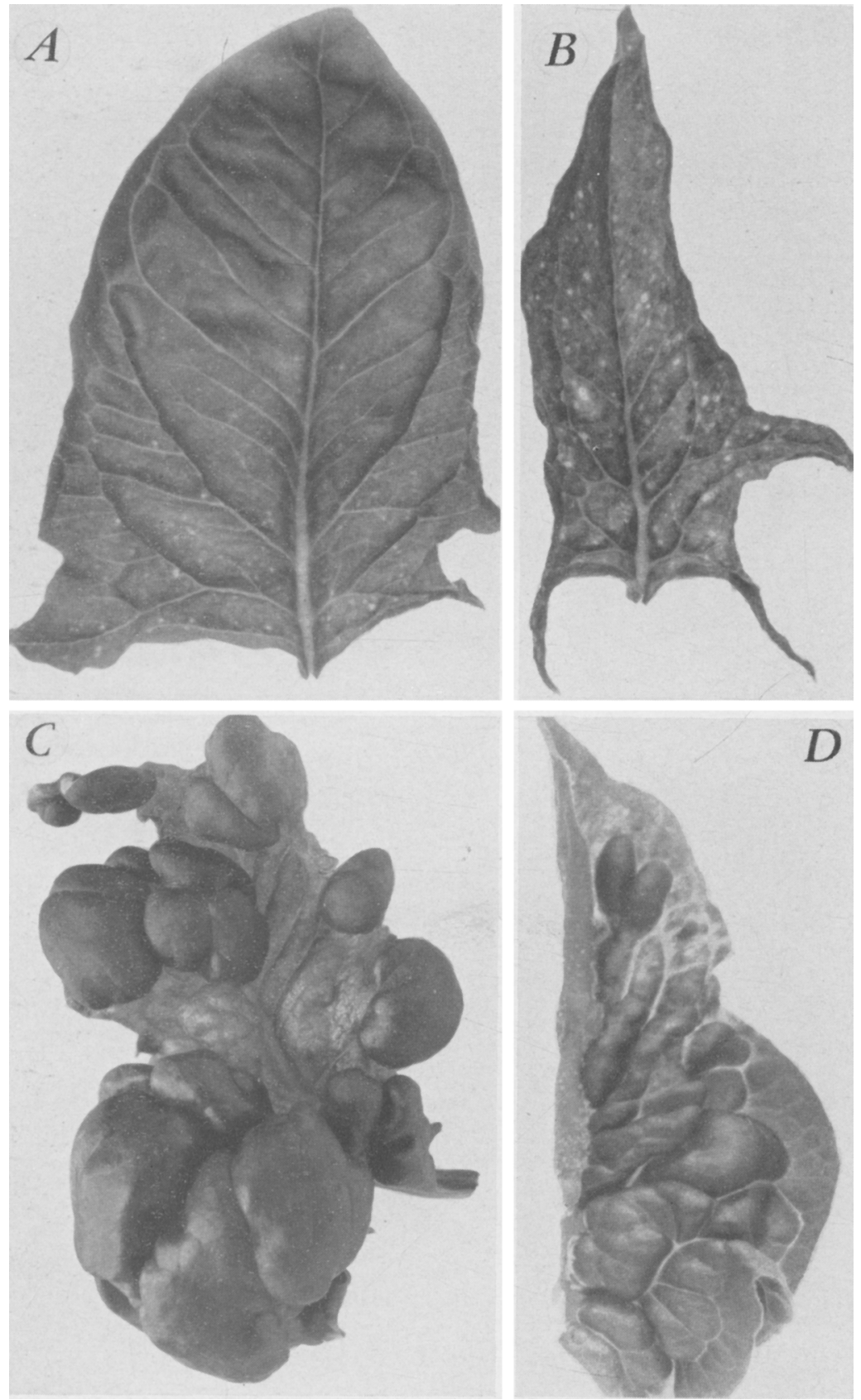

Plate 4. Symptoms of western cucumber mosaic on leares of experimentally infected Bloomsdale spinach: $A$, cleared reins and veinlets aceompanied by small, circular, chlorotic spots on youngest leaf; $B$, narrowed leaf showing numerous chlorotic spots, some fusing; $C, D$, malformed leaves with blisterlike elevations and apical chlorosis. 

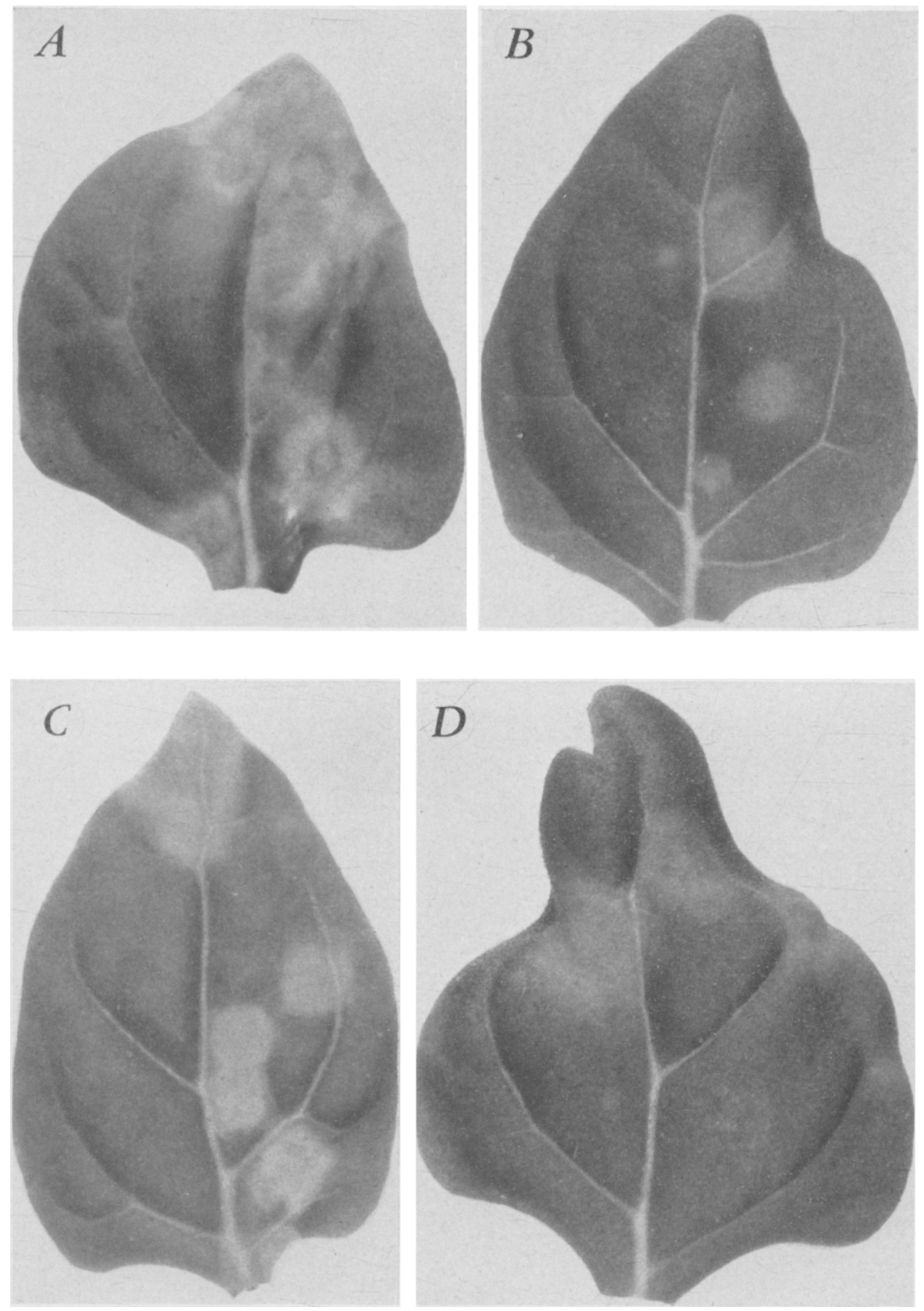

Plate 5. Symptoms of western eucumber mosaic on leaves of experimentally infected New Zealand spinach, Tetragonia expansa (family Aizoaceae): $A$, wide yellow or orange rings which surround green tissue; $B$, circular chlorotic areas; $C$, circular chlorotic areas fusing; $D$, malformed leaf with chlorotic areas. Blisterlike elevations and filamentous leaves, such as occur on spinach, have not been observed on this species. 

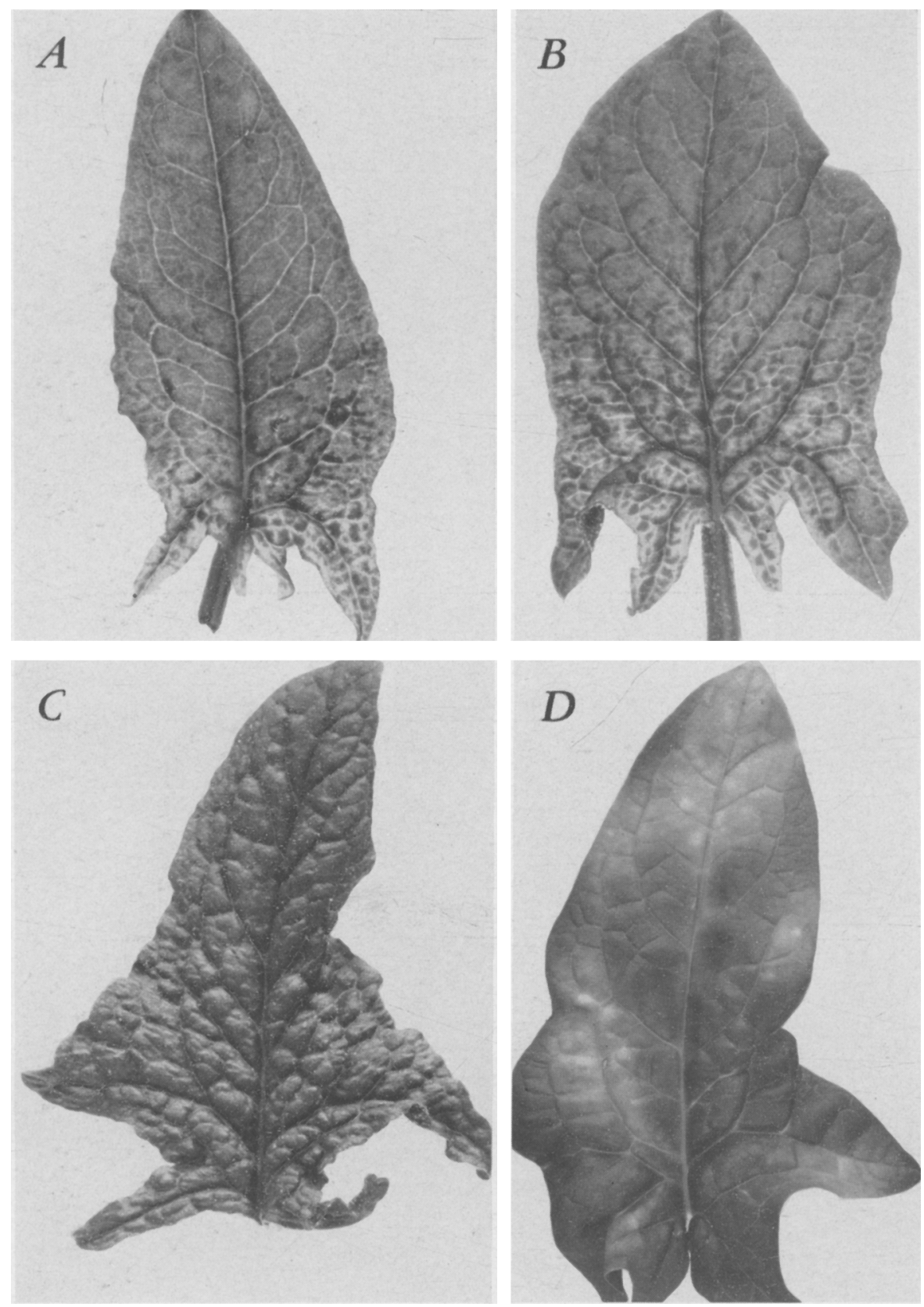

Plate 6. Symptoms of celery calico on leaves of experimentally infected Long Standing Bloomsdale spinach: $A, B$, youngest leaf, showing cleared veins and reinlets, surrounding green areas in $B ; C$, blisterlike elevations; $D$, oldest leaf showing orange or lemon-yellow discoloration. 

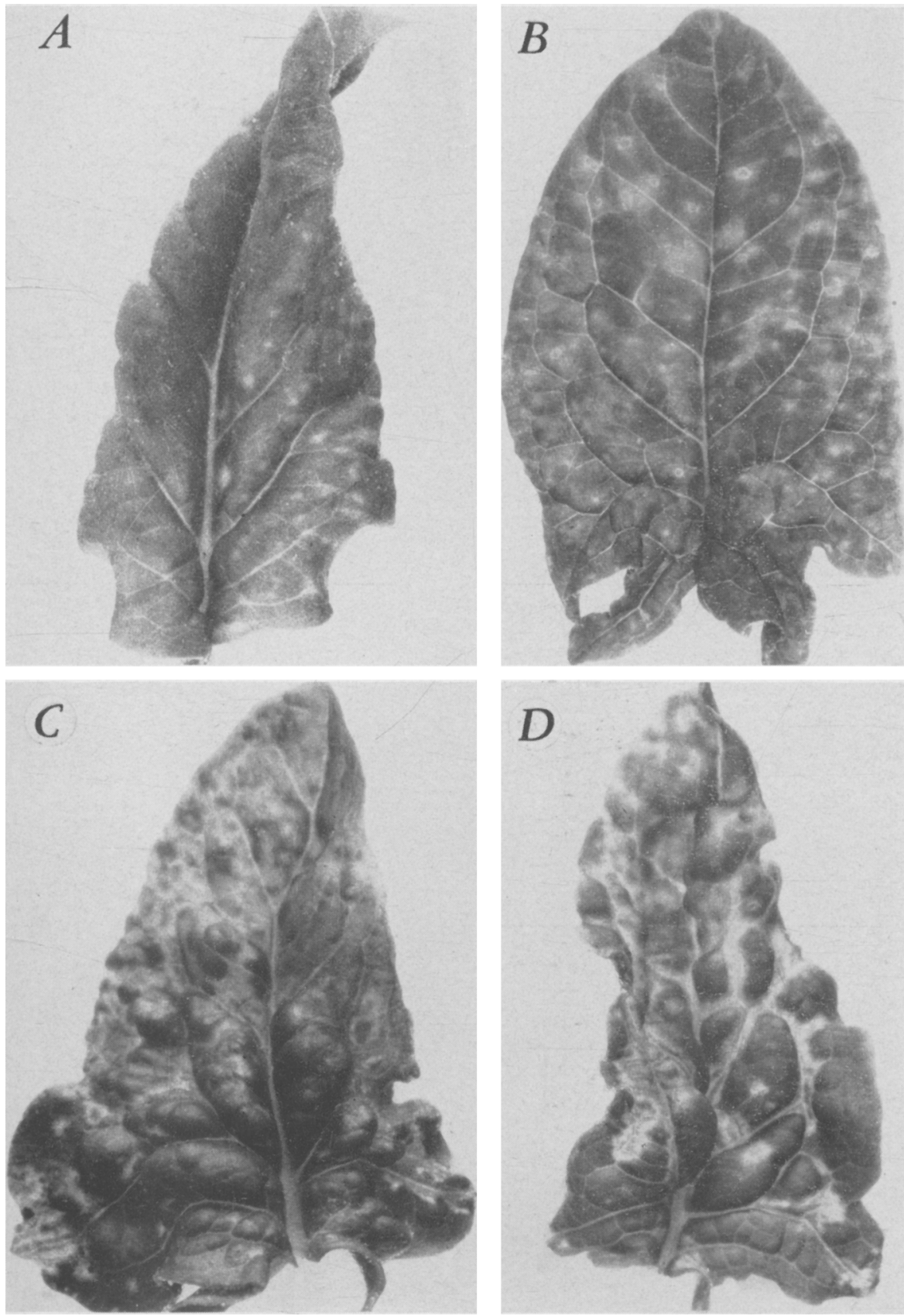

Plate 7 . Symptoms of sugar-beet mosaic on young leaves of Long Standing Bloomsdale spinach: $A$, small chlorotic areas on and between the reins; $B$, small, circular, chlorotic rings, each with a minute necrotic center; $C$, chlorosis and blisterlike elevations; $D$, blisterlike elerations and reinbanding. 

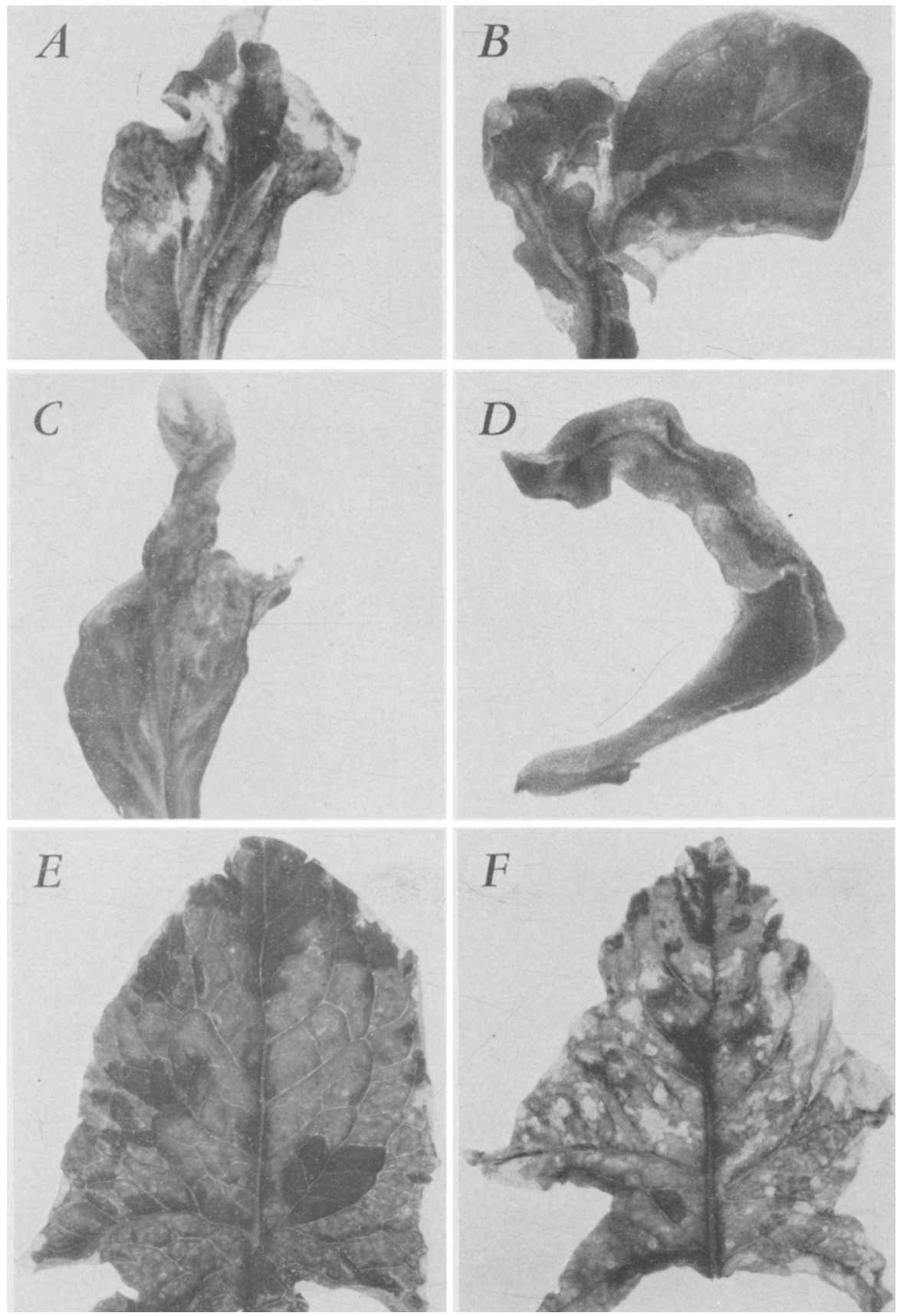

P'late 8. Symptoms of sugar-beet mosaic on leaves of Long Standing Bloomsdale spinach: $A, B$, dwarfed, malformed, young leaves showing blisterlike elevations; $C$, young leaf twisted along the midrib; $D$, young leaf folded along the midrib; $E$, old leaf showing large, irregular, chlorotic areas and dark-green blotches; $F$, old leaf showing necrosis along the margin and within the blade. 
The journal Hilgardia is published at irregular intervals, in volumes of about 600 pages. The number of issues per volume varies.

Subscriptions are not sold. The periodical is sent as published only to libraries, or to institutions in foreign countries having publications to offer in exchange.

You may obtain a single copy of any issue free, as long as the supply lasts; please request by volume and issue number from:

\section{Publications Office \\ College of Agriculture \\ Berkeley 4, California}

The limit to nonresidents of California is 10 separate issues on a single order. A list of the issues still available will be sent on request. 


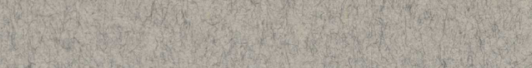

$x^{2}$

W. $4 x^{2}$ (1) (1) Thing

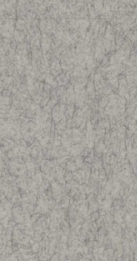

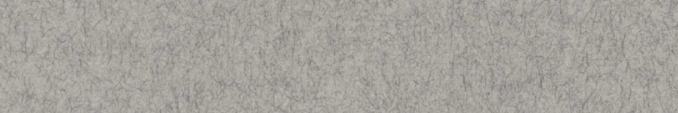

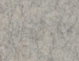

$x_{3},-1$

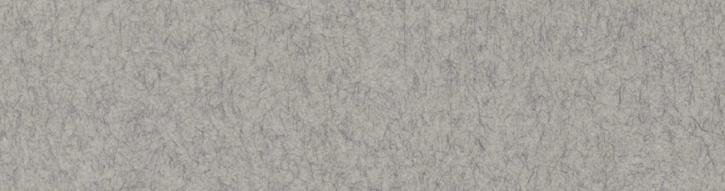

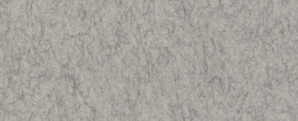

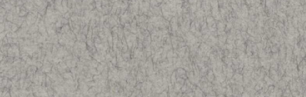

19.2.

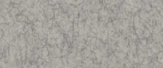

